\title{
Social-Ecological Change on the Mongolian Steppe: Herder Perceptions of Causes, Impacts, and Adaptive Strategies
}

\author{
Indiana Reid-Shaw ${ }^{1}$ (D) Azjargal Jargalsaihan ${ }^{2} \cdot$ Robin S. Reid $^{3} \cdot$ Chantsallkham Jamsranjav $^{4}$. \\ María E. Fernández-Giménez ${ }^{4,5}$
}

Accepted: 18 August 2021 / Published online: 3 November 2021

(C) The Author(s) 2021

\begin{abstract}
Pastoral people in rangelands worldwide are experiencing uncertainty due to a combination of climatic, economic, and political stressors. Our study seeks to create a full view of the drivers, impacts, and adaptations to change for livestock herders in rural Mongolia, making use of herder traditional knowledge and select instrumental data. Interview respondents described undesirable trends in livestock herds, pasture, wildlife, and their livelihoods in three sites in northern, central, and eastern Mongolia from 1995 to 2015, including decreased lake levels. There was more agreement for precipitation trends than for temperature. We developed a systems model based on herder descriptions of the sequence and prominence of interacting drivers of change. Finally, we describe measures herders are taking to adapt to these changes, such as more frequent livestock movement. We present a transdisciplinary view of social-ecological change and applications for more regionally focused governance in an era of climate uncertainty.
\end{abstract}

Keywords Social-Ecological Systems $\cdot$ Rangelands $\cdot$ Adaptation $\cdot$ Traditional Ecological Knowledge $\cdot$ Herders $\cdot$ Mongolia

\section{Introduction}

Indiana Reid-Shaw

ireidshaw@gmail.com

Azjargal Jargalsaihan

j.azjargal@gmail.com

Robin S. Reid

robin.reid@colostate.edu

Chantsallkham Jamsranjav

jchantsaa@gmail.com

María E. Fernández-Giménez

maria.fernandez-gimenez@colostate.edu

1 Environmental Studies, University of California Santa Cruz, Santa Cruz, CA 95060, USA

2 Nutag Action Research Institute, Ulaanbaatar, Mongolia

3 Department of Ecosystem Science and Sustainability, Fort Collins, CO, USA

4 Department of Forest and Rangeland Stewardship, Fort Collins, CO, USA

5 Center for Collaborative Conservation, Colorado State University, Fort Collins, CO 80523, USA
The extensive rangelands of the world support pastoral peoples, livestock, and wildlife in often harsh and variable climates, physically remote from human population and market centers. Recently, pasture users are experiencing greater environmental unpredictability in concert with economic and political change. Multi-faceted drivers of change threaten the future sustainability and resilience of rangeland ecosystems and their pastoral cultures (Galvin 2009; Reid et al. 2014). Climate change will alter ecosystem functioning in rangelands worldwide (Joyce et al. 2013). In most rangelands, precipitation will become more variable, in some latitudes increasing and others decreasing (Reid et al. 2014). Increasingly, there is demand for alternative uses of rangeland landscapes, such as for housing, cropland, and extractive industry development; these uses all restrict herding and wildlife movements (Galvin et al. 2008; Herrick et al. 2012). Broad-scale changes play out in different landscapes in unique ways, which means that localized understandings of change will be important to support place-based pastoral adaptations to change.

Climate change is affecting the temperate grasslands of Eurasia, known as the "steppe," that encompass $80 \%$ of the 
nation of Mongolia (Carbutt et al. 2017). In Mongolia, increased temperature and decreased precipitation have reduced water supply and forage yield, and shifted ecological zone boundaries, as drier zones take over wetter ones (Angerer et al. 2008; Jamsranjav et al. 2018). In conjunction with environmental shifts, dramatic sociopolitical changes have occurred in Mongolia. Following the collapse of communism in 1990, herder collectives were dismantled and livestock privatized (Ojima and Chuluun 2008). After two generations of steady income and social services from the Mongolian state during communism, herders assumed the role of individual business managers and took on the associated risks, leading many into poverty (Bruun and Odgaard 1996; Upton 2008). This decentralization led to greater influence from non-state actors, such as NGOs and the private sector (Upton 2008; Galvin 2009).

Resilient responses to change in Mongolia and elsewhere require in-depth understanding of the drivers and impacts of, and adaptations to, change at relatively local scales. Here, resilience is the capacity of a system, or an interconnected, organized set of components (Meadows and Wright 2008), to recover from and adapt to disturbances without losing functionality (Hruska et al. 2017). We construct a complex understanding of a rangeland social-ecological system by not only monitoring environmental change from different knowledge sources, but also considering livestock herders' descriptions of how they are responding to change (Kassam 2009; Goulden et al. 2016). We also consult herders' observations to help build a systems model linking the local to national scales that shows the system parts (e.g., rainfall, livestock), how those parts interact (e.g., one increasing the other) and what political, climatic, and ecological forces drive change in the system. It was only through Traditional Ecological Knowledge (TEK) that we could build this model, based on herder observations of their pastoral system over time.

TEK is "a system of experiential knowledge gained by continual observation transmitted among members of a community" (Huntington 1998:1). TEK, similar to Local Ecological Knowledge (LEK) or Indigenous Knowledge (IK), often includes a long-term perspective of change passed down through generations and can therefore detect early warnings of major disturbances (Agrawal 1995; Dumbe et al. 2018). In addition, combining TEK with scientific data in "hybrid knowledge" can produce a more comprehensive view of environmental change (Alexander et al. 2011; Gómez-Baggethun et al. 2013). Discrepancies between TEK and scientific findings provide new insights by highlighting what is still debated about ecological change (Davis and Wagner 2003; Klein et al. 2014). Hybrid knowledge and methodologies "may be equally valid" given the complexity of human-environment interactions in climate change adaptation research (Nightingale 2016). Here, we explore ways of combining hybrid knowledges and triangulating their findings. This helps counterbalance the epistemic power that scientific knowledge typically holds in climate change research with non-expert, everyday observations (ibid.).

In Mongolia, livestock herder knowledge (TEK) has been integrated and compared with scientific environmental knowledge since the 2000s (Fernández-Giménez 2000; Bruegger et al. 2014; Jamsranjav et al. 2019). For instance, both herder categorizations and scientific carrying capacity models identified the same indicators of best pasture conditions in Northern Mongolia (Kakinuma and Takatsuki, 2012). There is, however, still uncertainty as to how well the predictions of climate models align with herder observations of climate changes in rangelands across the varying natural zones of the Mongolian Plateau (e.g., FernándezGiménez et al. 2015). Few studies connect trend comparisons with local peoples' interpretations of why their environment is changing or what they are already doing to adapt to these environmental shifts (e.g., Wu et al. 2015). In Mongolia, few studies also ask herders what adaptation help they would need from outside actors, such as non-profit and government entities (Hahn 2018). It is important to understand herder perception because localized experience helps better identify the implications of change for livestock, wildlife, and people. Furthermore, community members often implement better practical solutions when they feel they have a stake in resource management and outcomes (Roba and Oba 2008; Danielson et al. 2010). A comprehensive understanding of the causes and dynamics of environmental change, as told by resource users, may improve local rangeland policy development (Lewison et al. 2016).

We seek to create a fuller view of the drivers, responses, and adaptations to environmental change in Mongolia, using both TEK and selected quantitative scientific data with four objectives: 1) to understand what environmental changes herders have experienced over the last 20 years across multiple ecological zones, 2) to compare meteorological data to herder observations of climatic changes, 3 ) to develop a comprehensive systems model of the drivers and impacts of environmental change according to herders, and 4) to document what strategies herders are already implementing and what assistance they seek to better adapt to environmental change in Mongolia.

\section{Methods}

\section{Study Sites}

Landlocked Mongolia (1000-1500 m.a.s.1.) spans several ecological zones from the Gobi Desert, which straddles the Mongolian border with China, to the forest taiga, which borders the Siberian part of Russia (Fig. 1; Ulziikhutag 


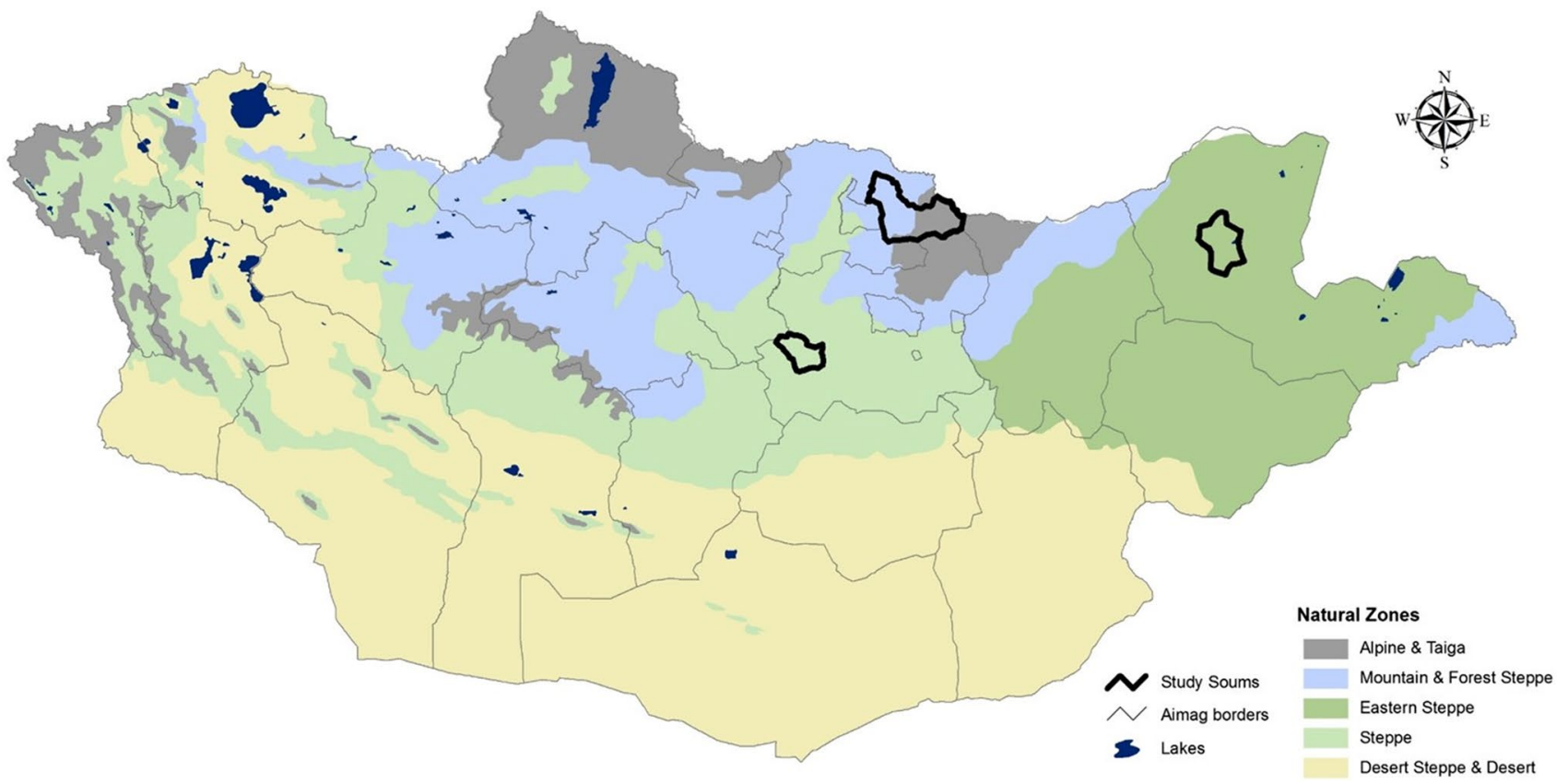

Fig. 1 Map of ecological zones and study sites in Mongolia (adapted by Michael Heiner from Akira Hirano, unpublished dataset: Natural Zones of Mongolia. Japan International Research Center for Agricultural Sciences. Tsukuba, Japan)

1989). Temperatures fluctuate from highs of $30^{\circ} \mathrm{C}$ in July to lows of $-40^{\circ} \mathrm{C}$ in January. Annual precipitation tends to be low, ranging from $50 \mathrm{~mm}$ in the desert and desert steppe to $500 \mathrm{~mm}$ in the mountain and forest steppe (Dagvadorj et al. 2009), with a growing season from May-August (Batjargal 1997). The political administration in Mongolia is divided into 21 aimags, or provinces, which are sub-divided into 331 soums, or counties, and then further into many baghs, or sub-county territories. About one quarter of the human population continues a semi-nomadic lifestyle moving seasonally (Fernández-Giménez 2000). In 2019, Mongolia supported 30 million sheep, 27 million goats, 4 million cattle, 3 million horses, and 0.4 million camels (National Statistical Office of Mongolia 2019).

To obtain a broad picture of herder experiences with climate change, we purposely selected study sites in ecological zones with contrasting climate histories, as measured by the instrumental record over the last two decades. We used the global meteorological dataset from the Climatic Research Unit (CRU) to identify three study soums in three zones (steppe, eastern steppe, and taiga/forest steppe) in central, eastern, and northern Mongolia (Harris et al. 2014). CRU Timeseries 3.21 data files were acquired for monthly maximum and minimum temperature (Tmax and Tmin) and precipitation (P) from the British Atmospheric Data Centre (Harris et al. 2014). Monthly grid values were derived from the $0.5 \times 0.5^{\circ}$ grid cells interpolated from anomalies of data and combined with existing climatologies sourced via CRU from the Mongolian Institute for Meteorology, Hydrology, and the
Environment (Venable et al. 2015; N. B. H. Venable pers. comm. 2016). Generally, 20-30 stations contributed nationally from 1993-2012. Station trends were analyzed using the non-parametric Mann-Kendall test, not biased by outliers or missing data, to determine the direction and significance of climate variable changes between 1993 and 2012 (Mann 1945; Venable et al. 2015; Fassnacht et al. 2018).

The three study soums principally differ by climate, vegetation, and livestock forage consumption. As measured by the CRU data, Undurshireet soum, in the steppe is the driest, and has become drier, not warmer or cooler over time. Sergelen soum, in the eastern steppe, has become both warmer (in the winter) and drier, and Yeroo soum, in the taiga, mountain and forest steppe, has become warmer (in the winter) but not drier over time. Livestock in Undurshireet consumed much more forage than in the other soums in 2014 ( $2 x$ the \% forage consumed compared to Sergelen and $10 \times$ the forage consumed in Yeroo) (Gao et al. 2015). The steppe is dominated by grasses, such as Stipa krylovii, and shrubs, such as Kochia prostrata (Bruegger et al. 2014). Sergelen, in the eastern steppe, has slightly higher mean annual rainfall than Undurshireet. The eastern steppe is known for its tall grasses, such as Stipa grandis, and large populations of white-tailed gazelle, or Procapra gutturosa. Yeroo, in the taiga, mountain and forest steppe has similar rainfall to Sergelen. The topography of Yeroo varies from flat grassland near the Selenge riverbed to a mountain pass with shrubs and trees, such as Larix siberica (Bruegger et al. 2014). 


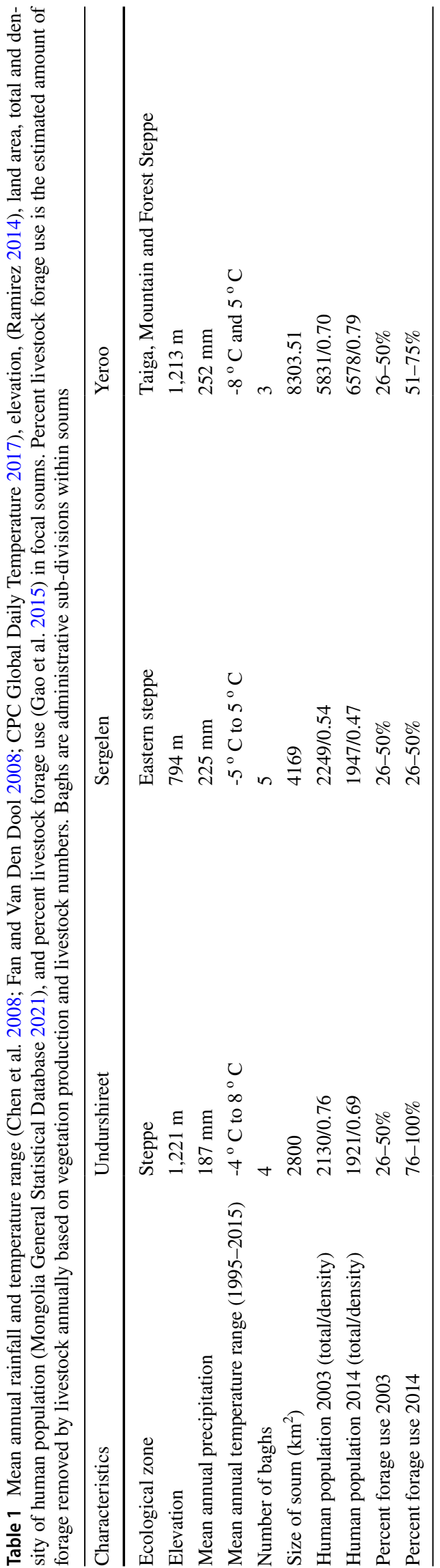

\section{Herder Observation Interviews}

Our goal was to record herders' observations of the drivers, impacts, and adaptations to broad environmental change. We thus developed a herder interview modified from a previous 2011 interview from the Mongolian Rangelands and Resilience (MOR2) project (Bruegger et al. 2014) to document direct personal observations of these changes. We used mixed methods, collecting both closed and open-ended responses. The 24 quantitative questions (e.g,. "kinds of plants," "lake levels") used a Likert scale ranging from least to most change observed. We asked herders to compare how weather patterns, water levels, and pastures changed over the last 20 years. We chose a 20-year period (1995-2015) because 1995 was a relatively memorable year for herders during the transition from socialism to capitalism (Sankey et al. 2009) and most herders we encountered had been herding over this entire time period. Our following 15 qualitative questions addressed why the observed rangeland changes they described occurred, how they adapted to them, and what kind of assistance they would need from the government or Community Based Rangeland Management (CBRM) programs. Community-Based Natural Resource Management (CBNRM), including CBRM, is an approach, varying in scope, where local users agree on rules and norms to manage natural resources (Agrawal and Gibson 2001; Ulambayar et al. 2017). Donor-supported, formally organized CBRMs emerged in Mongolia in the 1990s over pasture degradation concerns and under a global backdrop of community-level development and conservation (Fernández-Giménez et al. 2014). An oversight of our study design is that we did not explicitly include questions about local government, which has historically played a key role in Mongolian rangeland governance.

In the summer of 2015, the first two authors conducted 20 face-to-face interviews in each of the three study soums for a total of 60 interviews. We selected respondents with the help of local contacts, such as soum governors, who steered us to knowledgeable herders who had lived in the soum for at least 20 years. We then used peer referrals to guide us to other herders (Knapp and Fernández-Giménez 2009). We spatially distributed our interviews in each soum by conducting interviews with the same number of herders from each bagh. Interviewees ranged from 36 to 81 years old (average 51). We hoped to have the same number of male and female respondents, but in practice, males frequently assumed responsibility and the women stepped back (cf. Hopping et al. 2016). We therefore interviewed 18 female and 42 male-identifying herders. Interviews ranged from 30 min to one hour, and were conducted in Mongolian and translated into English by an interpreter. Audio-recorders were used to fill in gaps in interview notes. 
Table 2 Mongolian herders' responses $(n=60)$ to interview questions about climate conditions in 2015 in three soums compared to 20 years earlier. Count (and percentage) of Likert scale responses followed by mean (and standard error) of responses. Means in bold are significantly different for that soum compared with 20 years earlier at $p<.0025$. Means with no shared letters are significantly different from each other when comparing among soums at $p<.0025$

\begin{tabular}{|c|c|c|c|c|}
\hline Question & $\begin{array}{l}\text { Steppe } \\
\text { Response }\end{array}$ & $\begin{array}{l}\text { Undurshireet } \\
\text { Central } \\
(\boldsymbol{n}=\mathbf{2 0})\end{array}$ & $\begin{array}{l}\text { Sergelen } \\
\text { Eastern } \\
(\boldsymbol{n}=\mathbf{2 0})\end{array}$ & $\begin{array}{l}\text { Yeroo } \\
\text { Forest-Mountain } \\
(\boldsymbol{n}=\mathbf{2 0})\end{array}$ \\
\hline \multirow{6}{*}{$\begin{array}{l}\text { Average spring tempera- } \\
\text { tures: }\end{array}$} & $1=$ Much cooler & $11(55 \%)$ & $3(15 \%)$ & $9(45 \%)$ \\
\hline & $2=$ Cooler & $7(35)$ & $11(55)$ & $9(45)$ \\
\hline & $3=$ No change & $1(5)$ & $4(20)$ & $0(0)$ \\
\hline & $4=$ Warmer & $0(0)$ & $2(10)$ & $1(5)$ \\
\hline & $5=$ Much warmer & $0(0)$ & $0(0)$ & $0(0)$ \\
\hline & Not applicable & $1(5)$ & $0(0)$ & $1(5)$ \\
\hline \multicolumn{2}{|l|}{ Mean (Standard Error) } & $1.47(0.27)^{\mathrm{a}}$ & $2.25(0.27)^{\mathrm{a}}$ & $1.63(0.28)^{a}$ \\
\hline \multirow{6}{*}{$\begin{array}{l}\text { Average summer tem- } \\
\text { peratures: }\end{array}$} & $1=$ Much cooler & $8(40)$ & $2(10)$ & $4(20)$ \\
\hline & $2=$ Cooler & $5(25)$ & $9(45)$ & $9(45)$ \\
\hline & $3=$ No change & $0(0)$ & $5(60)$ & $4(20)$ \\
\hline & $4=$ Warmer & $4(20)$ & $4(20)$ & $0(0)$ \\
\hline & $5=$ Much warmer & $3(15)$ & $0(0)$ & $3(15)$ \\
\hline & Not applicable & $0(0)$ & $0(0)$ & $0(0)$ \\
\hline \multirow{7}{*}{$\begin{array}{l}\text { Mean (SE) } \\
\text { Average fall tempera- } \\
\text { tures: }\end{array}$} & & $2.45(0.35)^{\mathrm{a}}$ & $2.55(0.21)^{\mathrm{a}}$ & $2.45(0.29)^{\mathrm{a}}$ \\
\hline & $1=$ Much cooler & $2(10)$ & $0(0)$ & $5(25)$ \\
\hline & $2=$ Cooler & $6(5)$ & $1(5)$ & $5(25)$ \\
\hline & $3=$ No change & $4(20)$ & $14(70)$ & $8(40)$ \\
\hline & $4=$ Warmer & $5(60)$ & $5(25)$ & $1(5)$ \\
\hline & $5=$ Much warmer & $1(5)$ & $0(0)$ & $1(5)$ \\
\hline & Not applicable & $2(10)$ & $0(0)$ & $0(0)$ \\
\hline \multicolumn{2}{|l|}{ Mean (SE) } & $2.83(0.34)^{\mathrm{a}}$ & $3.20(0.12)^{\mathrm{a}}$ & $2.40(0.24)^{\mathrm{a}}$ \\
\hline \multirow{6}{*}{$\begin{array}{l}\text { Average winter tempera- } \\
\text { tures: }\end{array}$} & $1=$ Much cooler & $0(0)$ & $1(5)$ & $6(30)$ \\
\hline & $2=$ Cooler & $2(10)$ & $1(5)$ & $6(30)$ \\
\hline & $3=$ No change & $2(10)$ & $7(35)$ & $3(15)$ \\
\hline & $4=$ Warmer & $12(60)$ & $10(50)$ & $3(15)$ \\
\hline & $5=$ Much warmer & $1(5)$ & $1(5)$ & $0(0)$ \\
\hline & Not applicable & $3(15)$ & $0(0)$ & $2(10)$ \\
\hline \multicolumn{2}{|l|}{ Mean (SE) } & $3.71(0.27)^{\mathrm{a}}$ & $3.45(0.20)^{\mathrm{a}}$ & $2.21(0.37)^{b}$ \\
\hline \multirow[t]{6}{*}{ Amount of rainfall: } & $1=$ Decreased a lot & $14(70)$ & $4(20)$ & $18(90)$ \\
\hline & $2=$ Decreased a little & $3(15)$ & $5(25)$ & $1(5)$ \\
\hline & $3=$ About the same & $0(0)$ & $6(30)$ & $1(5)$ \\
\hline & $4=$ Increased a little & $2(10)$ & $4(20)$ & $0(0)$ \\
\hline & $5=$ Increased a lot & $0(0)$ & $1(5)$ & $0(0)$ \\
\hline & Not applicable & $1(5)$ & $0(0)$ & $0(0)$ \\
\hline \multicolumn{2}{|l|}{ Mean (SE) } & $1.74(0.32)^{\mathrm{a}}$ & $3.05(0.26)^{\mathrm{b}}$ & $1.15(0.11)^{\mathrm{a}}$ \\
\hline \multirow{6}{*}{$\begin{array}{l}\text { Duration of rainfall } \\
\text { events: }\end{array}$} & $1=$ Much shorter & $14(70)$ & $3(15)$ & $18(90)$ \\
\hline & $2=$ Shorter & $3(15)$ & $9(45)$ & $2(10)$ \\
\hline & $3=$ No change & $1(5)$ & $6(30)$ & $0(0)$ \\
\hline & $4=$ Longer & $0(0)$ & $2(10)$ & $0(0)$ \\
\hline & $5=$ Much longer & $1(5)$ & $0(0)$ & $0(0)$ \\
\hline & Not applicable & $1(5)$ & $0(0)$ & $0(0)$ \\
\hline \multicolumn{2}{|l|}{ Mean (SE) } & $1.47(0.33)^{\mathrm{a}}$ & $2.35(0.20)^{b}$ & $1.10(0.69)^{\mathrm{a}}$ \\
\hline \multirow[t]{3}{*}{ Rainfall intensity: } & $1=$ Much less intense & $0(0)$ & $2(10)$ & $0(0)$ \\
\hline & $2=$ Less intense & $1(5)$ & $3(15)$ & $1(5)$ \\
\hline & $3=$ No change & $3(15)$ & $4(20)$ & $2(10)$ \\
\hline
\end{tabular}


Table 2 (continued)

\begin{tabular}{|c|c|c|c|c|}
\hline Question & $\begin{array}{l}\text { Steppe } \\
\text { Response }\end{array}$ & $\begin{array}{l}\text { Undurshireet } \\
\text { Central } \\
(\boldsymbol{n}=\mathbf{2 0})\end{array}$ & $\begin{array}{l}\text { Sergelen } \\
\text { Eastern } \\
(\boldsymbol{n = 2 0})\end{array}$ & $\begin{array}{l}\text { Yeroo } \\
\text { Forest-Mountain } \\
(\boldsymbol{n}=\mathbf{2 0})\end{array}$ \\
\hline & $4=$ More intense & $3(15)$ & $7(35)$ & $2(10)$ \\
\hline & $5=$ Much more intense & $13(65)$ & $3(15)$ & $15(75)$ \\
\hline & Not applicable & $0(0)$ & $1(5)$ & $0(0)$ \\
\hline Mean (SE) & & $4.40(0.21)^{\mathrm{a}}$ & $3.32(0.29)^{\mathrm{b}}$ & $4.85(0.20)^{\mathrm{a}}$ \\
\hline \multirow{6}{*}{$\begin{array}{l}\text { Number of days } \\
\text { between rains: }\end{array}$} & $1=$ Many fewer & $0(0)$ & $0(0)$ & $1(5)$ \\
\hline & $2=$ Fewer & $1(5)$ & $1(5)$ & $0(0)$ \\
\hline & $3=$ No change & $1(5)$ & $3(15)$ & $1(5)$ \\
\hline & $4=$ More & $2(10)$ & $12(60)$ & $1(5)$ \\
\hline & $5=$ Many more & $15(75)$ & $4(20)$ & $17(85)$ \\
\hline & Not applicable & $1(5)$ & $0(0)$ & $0(0)$ \\
\hline Mean (SE) & & $4.63(0.20)^{\mathrm{a}}$ & $3.95(0.17)^{b}$ & $4.65(0.22)^{\mathrm{a}}$ \\
\hline \multirow[t]{4}{*}{ Speed of wind: } & $1=$ Declined & $0(0)$ & $0(0)$ & $0(0)$ \\
\hline & $2=$ No change & $2(10)$ & $5(25)$ & $1(5)$ \\
\hline & $3=$ Increased & $18(90)$ & $11(55)$ & $19(95)$ \\
\hline & Not applicable & $0(0)$ & $4(20)$ & $0(0)$ \\
\hline Mean (SE) & & $2.90(0.07)^{\mathrm{a}}$ & $2.69(0.12)^{\mathrm{a}}$ & $2.95(0.05)^{\mathrm{a}}$ \\
\hline
\end{tabular}

\section{Statistical Data Analysis}

We compared the degree of change herders perceived in the present compared with 20 years ago within each soum for each variable with a non-parametric Wilcoxen Rank Sum test in R-Studio (Wickham 2016). Due to multiple testing, we adjusted our threshold of significant change (compared to no change) to $p<0.0025$ with the Bonferroni test. We excluded the 'not applicable' responses ("I have no knowledge" in Mongolian) before running the statistical tests to avoid skewing the mean values. We then qualitatively compared the direction and significance of these reported changes in climate with the gridded monthly meteorological data, both over a 20 -year period. We used the non-parametric Kruskal-Wallis test in $\mathrm{R}$ to analyze the quantitative, ranked interview responses to see if differences in perceived level and direction of change were detected between any of the soums for each variable (Wickham 2016). Lastly, the Dunn post-hoc test with a Bonferroni adjustment informed which soums differed significantly from each other through pairwise comparisons for each variable (Pohlert 2016).

\section{Qualitative Data Analysis}

Two researchers independently identified initial codes from qualitative interview responses in Atlas TI and Microsoft
Excel (Bryman 2012). We then conducted open coding iteratively to generate themes and sub-codes (Auerbach and Silverstein 2003; Yehl 2009). Further axial coding allowed us to create a conceptual model showing the main environmental changes herders described and their connections (Corbin and Strauss 1990; Charmaz 2006; Bryman 2012). The systems model is not a comprehensive set of variables and their connections, it contains only strong connections between different social and ecological variables that herders mentioned as important and volunteered during the interviews. In the systems model we only included connections between system variables if at least three herders (15\% of each soum sample) mentioned the connection.

Our systems model seeks to display an interlinked relationship between social and environmental factors in a constantly evolving ecosystem (Lewison et al. 2016). In addition, our systems model shows the scale of drivers and their impacts through a series of descending rings from the source drivers in the outer ring to the core of the system in the innermost ring. Arrow boldness indicates which variables influence each other and how strong the connections are a plus or minus sign next to the variable conveys either a promoting or inhibiting relationship. This complex model is completely derived from herders' responses and may be used as starting point for deeper quantitative analyses (Lewison et al. 2016). 


\section{Results}

\section{Herder Observations of Changes in Three Ecological Zones}

Herders generally saw stronger climate changes for precipitation than for temperature from 1995 to 2015 in the three focal soums (Table 2). Across all soums, herders reported shorter and more spread-out rainfall events. In Undurshireet and Yeroo (not Sergelen), herders reported less but more intense rainfall. For all precipitation conditions, Sergelen herders reported milder change than either Undurshireet and Yeroo. Herders reported cooler springs in all soums, but especially Sergelen and Yeroo, where $90 \%$ of herders reported cooling. While $65 \%$ of Undurshireet herders reported warmer winter temperature trends over the last 20 years, $60 \%$ of Yeroo herders reported cooler temperatures.

Herders generally reported moderately strong to strong changes in pastures and water level conditions over the last 20 years (Table 3 ). Over $70 \%$ of herders in each soum saw lower water levels in lakes. Herders in both Undurshireet and Yeroo reported lower water volumes in rivers, less pasture growth, earlier browning of pastures, more frequent dust storms, and greater amounts of sand movement. Sergelen herder responses diverged from these two soums, although Yeroo herders tended to give the most consistent responses (low standard error) for pasture conditions compared with Undurshireet and Sergelen (Table 3).

\section{Comparing Herder Observations of Trends in Climate with Meteorological Trends}

There was about $56 \%$ consistency between herder climate observations and patterns from the CRU meteorological dataset for the three study areas over the last 20 years. This was determined by tallying the number of herder and meteorological dataset agreements (in significance and direction of change) for climate variables (Table 4). We did not detect differential compatibility between herder perceptions and meteorological data based on gender or age.

Although meteorological readings singled out Yeroo (not drier, warmer winters, Table 4) as the only soum without significant reductions in rainfall, Yeroo herders observed very large reductions in rainfall. Both datasets concur that Sergelen (drier, warmer winters) and Undurshireet (drier, not warmer or cooler) saw decreased rainfall, though the reduction was not reported as significant by herders in Sergelen.

For temperature, the CRU dataset and herders did not often agree. Herders reported cooler springs for Undurshireet and Yeroo, while stations measured no significant trends in spring temperature. For winter, herders in our study did not report the significant warming trends suggested meteorologically in Sergelen. In contrast, the winter warming reported by Undurshireet herders was absent in the meteorological data. Yeroo diverged most sharply with herders noting significant cooling in the winter when stations reported significant warming.

\section{Herders' Explanations for the Changes They Observe}

Herders described complex sequences among source drivers of change (outer ring, Fig. 2), intermediary drivers (middle ring), and the core of the system (inner ring). They also recognized a diversity of promoting and inhibiting relationships among environmental variables, including temperature, water level, and fire. They connect these environmental variables to social variables, such as herder livelihoods, pollution, and mining. Herders also identified some indirect cascading effects in the system. We did not ask them about feedbacks. While this systems model is complicated, it is clearly not all the possible connections that could occur in their system, only those herders reported.

Herders described three main source drivers, "global climate change", "externally driven land use change", and "local herder practices" (outer ring, Fig. 2) that originate at different scales. The broad-scale climate change drivers (warming and decreased rainfall) ultimately reduce livestock productivity, vegetation quality, and water levels while they increase dust storms, extreme weather events $(d z u d s)$, and delay pasture greening.

Herders also described regional and global socioeconomic source drivers. For instance, agriculture (commonly hay and rapeseed grains) occupies and diminishes grazing lands, instigating land disputes between livestock herders and farmers. A Yeroo herder reasoned that herders were confined to the river basin because "agriculture is now on the hillsides, which have the best pasture for the winter." Lastly, herders indicated a third grouping of local source drivers as the pasture users themselves. Herders move in response to pasture conditions and have recently observed growing livestock populations as external herders migrate into their soums from other aimags or soums. Additionally, local hunting activities reduce the number of wildlife herders observe in their pastures. An Undurshireet herder noted several species that have declined because of illegal hunting, including ibex (Capra sibirica) and argali sheep (Ovis ammon).

These source drivers affect a set of intermediary drivers that connect the social and biophysical source drivers to the central core elements of the system. The intermediary drivers are most numerous and best mirror the environmental conditions herders described, such as water levels and dust storms (Tables 2 and 3). Several intermediary drivers were reinforced by both the externally 
Table 3 Mongolian herders' responses $(n=60)$ to interview questions about pasture and water level conditions in 2015 in three soums compared to 20 years earlier. Count (and percentage) of Likert scale responses followed by mean (and standard error) of responses.
Means in bold are significantly different for that soum compared with 20 years earlier at $p<.0025$. Means with no shared letters are significantly different from each other when comparing among soums at $p<.0025$

\begin{tabular}{|c|c|c|c|c|}
\hline Question & $\begin{array}{l}\text { Steppe } \\
\text { Response }\end{array}$ & $\begin{array}{l}\text { Undurshireet } \\
\text { Central } \\
(\boldsymbol{n}=\mathbf{2 0})\end{array}$ & $\begin{array}{l}\text { Sergelen } \\
\text { Eastern } \\
(\boldsymbol{n = 2 0})\end{array}$ & $\begin{array}{l}\text { Yeroo } \\
\text { Forest-Mountain } \\
(\boldsymbol{n}=\mathbf{2 0})\end{array}$ \\
\hline \multirow[t]{6}{*}{ Amount of pasture growth: } & $1=$ Much lower & $15(75 \%)$ & $1(5 \%)$ & $16(80 \%)$ \\
\hline & $2=$ Somewhat lower & $2(10)$ & $8(40)$ & $4(20)$ \\
\hline & $3=$ About the same & $1(5)$ & $5(25)$ & $0(0)$ \\
\hline & $4=$ Somewhat higher & $2(10)$ & $6(30)$ & $0(0)$ \\
\hline & $5=$ Much higher & $0(0)$ & $0(0)$ & $0(0)$ \\
\hline & Not applicable & $0(0)$ & $0(0)$ & $0(0)$ \\
\hline Mean (Standard Error) & & $1.50(0.22)^{\mathrm{a}}$ & $2.80(0.21)^{\mathrm{b}}$ & $1.20(0.09)^{\mathrm{a}}$ \\
\hline \multirow[t]{4}{*}{ Number of different kinds of plants: } & $1=$ Declined & $13(65)$ & $6(30)$ & $18(90)$ \\
\hline & $2=$ No change & $3(15)$ & $6(30)$ & $2(10)$ \\
\hline & $3=$ Increased & $3(15)$ & $3(15)$ & $0(0)$ \\
\hline & Not applicable & $1(5)$ & $5(25)$ & $0(0)$ \\
\hline Mean (SE) & & $1.47(0.21)^{\mathrm{ab}}$ & $1.80(0.26)^{\mathrm{a}}$ & $1.10(0.09)^{b}$ \\
\hline \multirow[t]{6}{*}{ Amount of bare ground: } & $1=$ Much less & $1(5)$ & $0(0)$ & $1(5)$ \\
\hline & $2=$ Somewhat less & $1(5)$ & $0(0)$ & $0(0)$ \\
\hline & $3=$ No change & $3(15)$ & $11(55)$ & $1(5)$ \\
\hline & $4=$ Somewhat more & $4(20)$ & $6(30)$ & $2(10)$ \\
\hline & $5=$ Much more & $11(55)$ & $3(15)$ & $16(80)$ \\
\hline & Not applicable & $0(0)$ & $0(0)$ & $0(0)$ \\
\hline Mean (SE) & & $4.15(0.26)^{a b}$ & $3.60(0.17)^{\mathrm{a}}$ & $4.60(0.07)^{b}$ \\
\hline \multirow[t]{6}{*}{ Frequency of dust storms: } & $1=$ Decreased a lot & $0(0)$ & $0(0)$ & $0(0)$ \\
\hline & $2=$ Decreased a little & $0(0)$ & $2(10)$ & $0(0)$ \\
\hline & $3=$ About the same & $1(5)$ & $8(40)$ & $1(5)$ \\
\hline & $4=$ Increased a little & $3(15)$ & $5(25)$ & $1(5)$ \\
\hline & $5=$ Increased a lot & $15(75)$ & $2(10)$ & $18(90)$ \\
\hline & Not applicable & $1(5)$ & $3(15)$ & $0(0)$ \\
\hline Mean (SE) & & $4.73(1.40)^{\mathrm{a}}$ & $3.41(0.76)^{\mathrm{b}}$ & $4.85(0.24)^{\mathrm{a}}$ \\
\hline \multirow[t]{6}{*}{ Amount of sand movement: } & $1=$ Much less & $0(0)$ & $0(5)$ & $0(0)$ \\
\hline & $2=$ Somewhat less & $0(0)$ & $1(0)$ & $0(0)$ \\
\hline & $3=$ About the same & $2(10)$ & $8(40)$ & $2(10)$ \\
\hline & $4=$ Somewhat more & $3(15)$ & $5(25)$ & $3(15)$ \\
\hline & $5=$ Much more & $15(75)$ & $3(15)$ & $15(75)$ \\
\hline & Not applicable & $0(0)$ & $3(15)$ & $0(0)$ \\
\hline Mean (SE) & & $4.65(0.15)^{\mathrm{a}}$ & $3.59(0.24)^{\mathrm{b}}$ & $4.65(0.15)^{\mathrm{a}}$ \\
\hline \multirow[t]{6}{*}{ River volume: } & $1=$ Decreased a lot & $19(95)$ & $4(20)$ & $20(100)$ \\
\hline & $2=$ Decreased a little & $1(5)$ & $8(40)$ & $0(0)$ \\
\hline & $3=$ No change & $0(0)$ & $2(10)$ & $0(0)$ \\
\hline & $4=$ Increased a little & $0(0)$ & $5(25)$ & $0(0)$ \\
\hline & $5=$ Increased a lot & $0(0)$ & $0(0)$ & $0(0)$ \\
\hline & Not applicable & $0(0)$ & $1(5)$ & $0(0)$ \\
\hline Mean (SE) & & $1.05(0.05)^{\mathrm{a}}$ & $2.79(0.31)^{\mathrm{b}}$ & $1.00(0.00)^{\mathrm{a}}$ \\
\hline \multirow[t]{4}{*}{ Lake levels: } & $1=$ Much lower & $13(65)$ & $11(55)$ & $14(70)$ \\
\hline & $2=$ Lower & $2(10)$ & $4(20)$ & $0(0)$ \\
\hline & $3=$ No change & $0(0)$ & $4(20)$ & $1(5)$ \\
\hline & $4=$ Higher & $0(0)$ & $1(5)$ & $0(0)$ \\
\hline
\end{tabular}


Table 3 (continued)

\begin{tabular}{|c|c|c|c|c|}
\hline Question & $\begin{array}{l}\text { Steppe } \\
\text { Response }\end{array}$ & $\begin{array}{l}\text { Undurshireet } \\
\text { Central } \\
(\boldsymbol{n}=\mathbf{2 0})\end{array}$ & $\begin{array}{l}\text { Sergelen } \\
\text { Eastern } \\
(\boldsymbol{n}=\mathbf{2 0}) \\
\end{array}$ & $\begin{array}{l}\text { Yeroo } \\
\text { Forest-Mountain } \\
(\boldsymbol{n}=\mathbf{2 0}) \\
\end{array}$ \\
\hline & $5=$ Much higher & $0(0)$ & $0(0)$ & $0(0)$ \\
\hline & Not applicable & $5(25)$ & $0(0)$ & $5(25)$ \\
\hline Mean (SE) & & $1.33(0.56)^{\mathrm{a}}$ & $1.75(0.22)^{\mathrm{a}}$ & $1.33(0.57)^{\mathrm{a}}$ \\
\hline \multirow[t]{6}{*}{ Peak time of river flow: } & $1=$ Much earlier & $0(0)$ & $1(5)$ & $1(5)$ \\
\hline & $2=$ Earlier & $0(0)$ & $0(0)$ & $1(5)$ \\
\hline & $3=$ No change & $1(5)$ & $9(45)$ & $2(10)$ \\
\hline & $4=$ Later & $6(30)$ & $5(25)$ & $0(0)$ \\
\hline & $5=$ Much later & $8(40)$ & $3(15)$ & $7(35)$ \\
\hline & Not applicable & $5(25)$ & $2(10)$ & $9(45)$ \\
\hline Mean (SE) & & $4.47(0.21)^{\mathrm{a}}$ & $3.32(0.29)^{\mathrm{a}}$ & $4.00(0.20)^{\mathrm{a}}$ \\
\hline \multirow[t]{6}{*}{ Snow melt: } & $1=$ Much earlier & $4(20)$ & $2(10)$ & $7(35)$ \\
\hline & $2=$ Earlier & $5(25)$ & $5(25)$ & $3(15)$ \\
\hline & $3=$ No change & $6(30)$ & $5(25)$ & $1(5)$ \\
\hline & $4=$ Later & $2(10)$ & $7(35)$ & $4(20)$ \\
\hline & $5=$ Much later & $1(5)$ & $1(5)$ & $4(20)$ \\
\hline & Not applicable & $2(10)$ & $0(0)$ & $1(5)$ \\
\hline Mean (SE) & & $2.50(0.36)^{\mathrm{a}}$ & $3.00(0.25)^{\mathrm{a}}$ & $2.74(0.41)^{\mathrm{a}}$ \\
\hline \multirow[t]{6}{*}{ Timing when grass turns green: } & $1=$ Much earlier & $0(0)$ & $0(0)$ & $0(0)$ \\
\hline & $2=$ Earlier & $2(10)$ & $3(15)$ & $0(0)$ \\
\hline & $3=$ No change & $2(10)$ & $10(50)$ & $2(10)$ \\
\hline & $4=$ Later & $10(50)$ & $6(30)$ & $3(15)$ \\
\hline & $5=$ Much later & $4(20)$ & $1(5)$ & $14(70)$ \\
\hline & Not applicable & $2(10)$ & $0(0)$ & $1(5)$ \\
\hline Mean (SE) & & $3.89(0.25)^{\mathrm{a}}$ & $3.21(0.18)^{\mathrm{a}}$ & $4.63(0.17)^{b}$ \\
\hline \multirow[t]{6}{*}{ Timing when grass turns brown: } & $1=$ Much earlier & $6(30)$ & $1(5)$ & $9(45)$ \\
\hline & $2=$ Earlier & $11(55)$ & $5(25)$ & $3(15)$ \\
\hline & $3=$ No change & $1(5)$ & $11(55)$ & $7(35)$ \\
\hline & $4=$ Later & $0(0)$ & $2(10)$ & $1(5)$ \\
\hline & $5=$ Much later & $1(5)$ & $1(5)$ & $0(0)$ \\
\hline & Not applicable & $1(5)$ & $0(0)$ & $0(0)$ \\
\hline Mean (SE) & & $1.89(0.30)^{\mathrm{a}}$ & $2.85(0.20)^{\mathrm{b}}$ & $2.00(0.23)^{\mathrm{a}}$ \\
\hline
\end{tabular}

driven land use and global climate change source drivers, such as an increase in dust storms and a decrease in forest abundance. Some intermediary drivers were coproduced by externally driven land use and "local herder practices," such as increased livestock numbers and river pollution (Fig. 2).

The core elements of the herding system are people, pasture, livestock, and wildlife. To herders, these were the parts of the system that felt the ultimate impacts of the source and intermediary drivers. Each core element had at least two drivers connected to it. We defined "Herder Livelihood" based on our interviews as the health, safety, and prosperity of pastoral families in the three study soums. "Livestock production" refers to the herd health of sheep, cattle, horses, etc., and in turn the quality and quantity of their products for sustenance and sale: milk, meat, cashmere, etc. We define "vegetation quality" as the diversity, health, and endemicity of species of shrubs and grasses on which livestock and wildlife graze. Lastly, herders referred to wildlife presence as the abundance of fauna, such as wolf, marmot, sacred falcon, and fish that they observe in their rangelands.

Herders also considered some connections more important than others. We quantified this with the thickness of the arrows in the model corresponding to a certain number of respondents (Fig. 2; Charmaz 2006). For example, under global climate change, declines in rainfall were mentioned more frequently than increases in wind speed. Under 
Table 4 Characteristics and climate trends in focal soums (CRU/ herder data). Significance from 1993-2012 ( $p<0.05$, Mann-Kendall test) based on the Mongolia-wide $0.5^{\circ} \times 0.5^{\circ}$ gridded CRU meteorological station file dataset (Harris et al. 2014; Venable et al. 2015;
Venable 2016). This is followed by significance from 1995-2015 $(p<.0025$, Wilcoxen Rank Sum test) from herder Likert scale responses about climate conditions. $+=$ significant increase, $-=$ significant decrease, $\mathrm{ns}=$ not significant

\begin{tabular}{llll}
\hline & Undurshireet & Sergelen & Yeroo \\
\hline Climatic Trends & & Meteorological records/Herder perceptions & $\mathrm{ns} /-$ \\
Spring max temp & $\mathrm{ns} /-$ & $\mathrm{ns} / \mathrm{ns}$ & $\mathrm{ns} /-$ \\
Spring min temp & $\mathrm{ns} /-$ & $\mathrm{ns} / \mathrm{ns}$ & $\mathrm{ns} / \mathrm{ns}$ \\
Summer max temp & $\mathrm{ns} / \mathrm{ns}$ & $\mathrm{ns} / \mathrm{ns}$ & $\mathrm{ns} / \mathrm{ns}$ \\
Summer min temp & $\mathrm{ns} / \mathrm{ns}$ & $\mathrm{ns} / \mathrm{ns}$ & $\mathrm{ns} / \mathrm{ns}$ \\
Fall max temp & $\mathrm{ns} / \mathrm{ns}$ & $\mathrm{ns} / \mathrm{ns}$ & $\mathrm{ns} / \mathrm{ns}$ \\
Fall min temp & $\mathrm{ns} / \mathrm{ns}$ & $\mathrm{ns} / \mathrm{ns}$ & $+/-$ \\
Winter max temp & $\mathrm{ns} /+$ & $+/ \mathrm{ns}$ & $+/-$ \\
Winter min temp & $\mathrm{ns} /+$ & $+/ \mathrm{ns}$ & $\mathrm{ns} /-$ \\
Total annual ppt & $-/-$ & $-/ \mathrm{ns}$ & Not drier, warmer winters \\
Summary of meteorological & Drier, not warmer or cooler & Drier, warmer winters & Drier, cooler springs and warmer \\
$\quad$ data & & & winters \\
Summary of herder observa- & Drier, cooler springs and warmer & No changes & \\
tions & winters & & \\
\hline
\end{tabular}

local herding practices, herders considered hunting as more influential to the system than actions of their herder groups. Some of the most common connections were: fire impacts herder livelihoods, such as structure safety; mining reduces water levels and increases river pollution; and grasshoppers and rodents decrease vegetation quality.

Finally, not all connections appeared in all soums (colorcoded arrows in Fig. 2). Grassland fires, for example, were an important source driver only in Yeroo and Sergelen, and city waste contributed to river pollution only in Undurshireet. In general, the climate drivers had the most universal influence on the system across soums, compared to externally driven land use and local herder practices, which were more location specific.

\section{Herders' Adaptations and Solutions}

In addition to the reasoning behind the changes they had observed over the last 20 years, herders described the measures they are currently taking to adapt to these changes (Table 5). For example, to allow for more pasture recovery, herders noted the importance of moving their gers (felted tents) and livestock more frequently and better distributing their animals across the steppe. In an effort to mitigate rising inflation in consumer goods and livestock populations, herders recommended that they export some of their animals. "We can sell offspring for products, such as meat or wool," explained one Undurshireet herder.
When we asked about government intervention, most herders interpreted this as the national government of Mongolia, which could implement wide-reaching policies. However, some respondents mentioned potential regionally (aimag) and locally (soum and bag) coordinated improvements. Herders discussed government adaptation strategies, such as managing increased livestock numbers by initiating a tax for owning over a certain number of animals (Table 5). Lastly, herders attributed adaptation strategies to CBRMs, such as holding meetings and conducting fencing studies. Some recommendations were shared among all three soums, such as suggesting that the government curtail mining operations for human and livestock health. Other recommendations were more suited to the specifics of a certain soum location. Only herders in Yeroo recommended stricter agricultural management due to their local conflicts over land access.

Interviewees allocated some roles to both herders and the government, such as cleaning rivers, but to differing degrees. They suggested herders could help with clean ups at the soum level, but the government regulate pollution sources upstream, such as those caused by factories in the capital, Ulaanbaatar. Herders in our study perceived that they shared adaptation responsibility with communal pasture groups, such as for pasture reservation and rotation. Some roles herders did not see as their responsibility, such as planting hay fodder. 
Fig. 2 A systems model of drivers of change and subsequent impacts based on qualitative analysis of herder responses. $+=$ increasing trends, $-=$ decreasing trends. Thicker arrows mean more herders mentioned this connection. The three colors indicate the three study soums

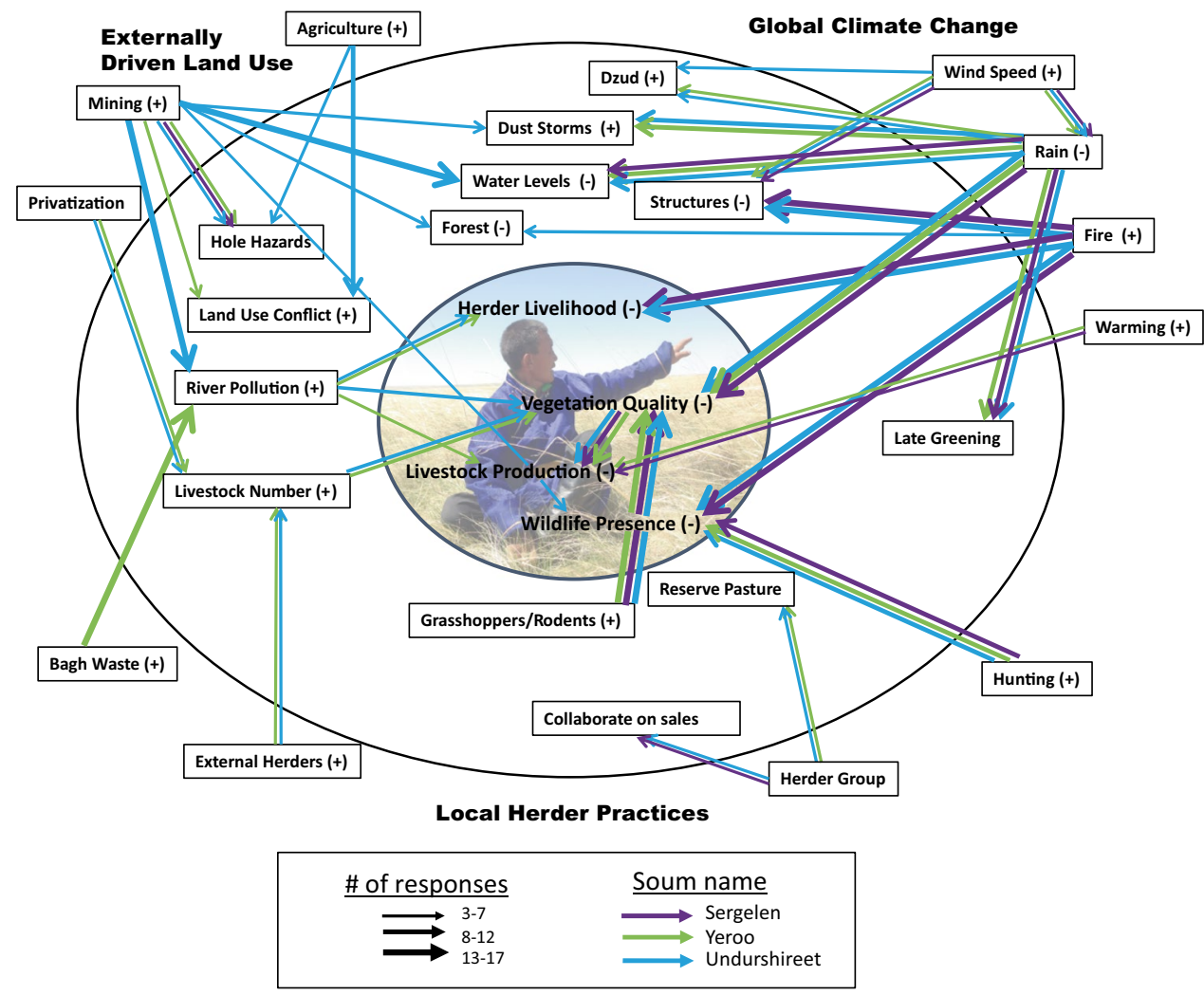

\section{Discussion}

\section{Trends in Herder Observations of Environmental Change}

Overall, herders described how climate, pasture, and water level conditions have shifted from 1995 to 2015 across central, eastern, and northern Mongolia. Every Yeroo herder in our study reported shorter rainfall events compared with $61 \%$ of herders who observed this in a similar study in Lake Hövsgöl, Mongolia, to the northwest of Yeroo (Goulden et al. 2016). One Yeroo herder commented: "Rainfall is much shorter; it rains for 1 to 2 hours instead of days on end." Herder observations of short and often intense rains may correspond with increased thunderstorm activity in northern Mongolia over the last 60 years (Goulden et. al 2016). Herders in all three soums also observed more days between rains, echoing Tajik and Afghan herder observations in the Pamir Mountains (Kassam 2009).

Herders generally saw stronger changes in climate for precipitation compared with temperature across the focal soums from 1995 to 2015 (Table 2). Globally, herders make similar observations perhaps because temperature change is more subtle and harder to detect than rainfall or its effects on livestock and rangeland condition (Strauss and Orlove 2003;
Marin 2010). A study in Tibet found that herders interpreted 'climate' in terms of vegetation and livestock observations rather than in terms related to temperature (Yeh 2016).

Nonetheless, herders in our study observed a strong trend in cooler spring temperatures (70\% in Sergelen and 90\% in both Undurshireet and Yeroo). "March and April are colder. May is colder and windy," explained a herder from Sergelen. A herder from Undurshireet described spring as just another winter. Herders interviewed in 2011 also observed cooling spring temperatures in comparison to 20 years ago in Bayankhongor, a desert-steppe aimag (Venable et al. 2012), as well as a majority of herders in a multiple soum Mongolian study (Fernández-Giménez et al. 2015). Local informants in the Pamir Mountains (Kassam 2009) and in Nyenrong and Amdo County, Tibet (Klein et al. 2014), also observed spring cooling. In the Tibetan case, cooler springs were often observed in conjunction with delayed green-up, a phenological trend also present in our study, especially in the forest steppe of Yeroo (Klein et al. 2014).

Increased dust storms were reported by $95 \%$ of herders in Yeroo, 90\% in Undurshireet, and 35\% in Sergelen. One herder in Yeroo lamented that she "can't prepare dairy products" like she used to when "there is so much dust" [in the air]. Another Yeroo herder described sandstorms so large that a sand pile covered his animal shelter. Dust storms are a natural phenomenon in Asian drylands but are 
exacerbated by changes in climate and land use (Sternberg and Edwards 2017; Middleton 2018). Such storms were considered "unusually frequent and intense" by herders in the desert-steppe region of Mongolia in comparison with the past (Marin 2010: 173). Herders in our study attributed dust events to overall drying, increased wind speeds, and mining activity (Fig. 2). Recent studies confirm the impacts of wind on dust in Mongolia (Sternberg and Edwards 2017; Middleton 2018). Research in the southern Gobi region show mining's role in spreading dust, especially from unpaved mining roads (Jackson 2015; Sternberg and Edwards 2017). Dust can damage both human and livestock health (Orgil et al. 2011; Lkhasuren 2012).

\section{Regional Variation: Comparing Observations from the Steppe to the Taiga}

For the majority of climate and pasture variables, herders did not observe the same degree of change across the three different ecological zones. This indicates that uniform strategies to address environmental change across Mongolia's landscape are likely not appropriate. Other herder-informed studies have further detected within-zone differences between soums, suggesting that coarse-resolution meteorological measurements may not be localized enough to inform best policies on their own (Fernández-Giménez et al. 2015).

The greatest regional variation in our study was in the soum of Sergelen where herders reported significantly milder environmental change across $45 \%$ of variables compared with the other two soums. In contrast to the reports of decreased rainfall, reduced river volume, and vegetation loss in the other soums, a Sergelen herder explained that they had "very good rain in the last few years," that "water in wells has flowed a lot," and that "very soft and watery rain in the last three years has helped recover the vegetation." The eastern steppe soum of Sergelen falls between Undurshireet and Yeroo in precipitation, temperature range, and elevation (Table 1). Its eastern-most geography, plant productivity, and low human population, however, set it apart. Sergelen is also the only study soum (Table 1) where percent forage use by livestock has stayed the same and unusually low from 2003-2014. Herders in Undurshireet and Yeroo attributed vegetation loss to increased livestock numbers, while this was not mentioned in Sergelen (Fig. 2). Pastures in the eastern steppe were found to have some of the lowest levels of livestock impacts on plant production, bare ground, and soil erosion as well as the highest levels of plant patch connectivity compared to other ecological zones in Mongolia in 2011 (Jamsranjav et al. 2018).

Unlike Sergelen, Yeroo herders reported the strongest and most consistent, negative changes in environmental conditions from 1995 to 2015. The mountain steppe region of Mongolia, like Yeroo, has seen the most climate change due to the region's high latitude and elevation (Angerer et al. 2008; Fernández-Giménez et al. 2015; Khishigbayar et al. 2015). Furthermore, Yeroo has the highest human population density compared with Undurshireet and Sergelen (Table 1). Population in addition to proximity to the city of Darkhan may contribute to substantial competing land uses in Yeroo.

\section{Comparing Knowledge Sources}

We compared how well herder-described climate trends matched models derived from meteorological stations. There is difficulty in integrating these knowledge systems because each brings its own scale of reference and biases (Somerville et al. 2011; La Frenierre and Mark 2017). Although trend analyses can be less robust over short time scales, we used a similar 20-year time scale as a comparison tool between the two knowledge sources.

In remote areas such as much of Mongolia, which also has a high degree of inter-annual variability, weather stations are sparse and may not produce comprehensive reporting (Shiklomanov et al. 2002; Harris et al. 2014). Disproportionate representation can potentially impact our meteorological data with different numbers of stations contributing to grids. We also suggest that modelled gridded data like CRU is not at the same scale as herder observations of changes in their landscapes over time (Fassnacht et al. 2018).

There are also issues with human observation over time. Faulty memory as well as cultural values, personal experiences, and extreme events may provide biases in herder observations over longer time scales (Knapp and FernándezGiménez, 2009; Gantuya et al. 2021).

Despite these caveats, there is rich insight to gain by comparing knowledge sources. In this study herder and meteorological observations of climate at the soum scale quite often matched each other. In a Mongolian study of six soums, both herder observations and meteorological station data matched for 20-year declining rainfall trends in the two steppe and two desert steppe soums (Fernández-Giménez et al. 2015), similar to our steppe results. Additionally, Fassnacht and colleagues (2018) found that herder and meteorological sources matched for decreasing precipitation in the Mongolian forest-steppe soums of Erdenemandal, and Tsesterleg, but not for Bayankhongor (steppe) or Khoriult (desert steppe; Fastnacht et al. 2018). Thus, of the three studies, ours showed the least match between herder observations and meteorological data for rainfall. In addition, mismatches between the two knowledge sources occurred more often with temperature data, particularly the strong spring cooling trend reported by herders but not supported by the meteorological station data (this study, Fernández-Giménez et al. 2015). 
Table 5 Herders' adaptations to environmental changes and their recommendations for assistance from government and Community Based Rangeland Management programs, or CBRMs

\begin{tabular}{|c|c|c|c|}
\hline & Herder Adaptation & Government & CBRM \\
\hline Increasing River Pollution & $\begin{array}{l}\text { - Clean river } \\
\text { - Pick up litter } \\
\text { - Stop mining }\end{array}$ & $\begin{array}{l}\text { - Clean water } \\
\text { - Stop leather factories from } \\
\text { polluting }\end{array}$ & \\
\hline Increasing Livestock Numbers & $\begin{array}{l}\text { - Sell animal products } \\
\text { - Reduce livestock numbers }\end{array}$ & $\begin{array}{l}\text { - Manage animal product } \\
\text { sales } \\
\text { - Manage carrying capacity } \\
\text { - Update veterinary services } \\
\text { - Manage livestock quality } \\
\text { - Stop external herders }\end{array}$ & $\begin{array}{l}\text { - Connect live- } \\
\text { stock products } \\
\text { to markets } \\
\text { - Calculate live- } \\
\text { stock population } \\
\text { and carrying } \\
\text { capacity }\end{array}$ \\
\hline Declining Vegetation Quality & $\begin{array}{l}\text { - Water pastures } \\
\text { - Move gers and livestock } \\
\text { more } \\
\text { - Reserve and rotate pastures } \\
\text { - Remove harmful plants } \\
\text { - Reduce rodents }\end{array}$ & $\begin{array}{l}\text { - Water pastures } \\
\text { - Manage/Stop mining } \\
\text { - Manage agriculture } \\
\text { - Plant hay fodder } \\
\text { - Make new roads to access } \\
\text { pastures } \\
\text { - Stop selling land and sacred } \\
\text { places } \\
\text { - Provide better fencing } \\
\text { - Manage grasshoppers }\end{array}$ & $\begin{array}{l}\text { - Water pastures } \\
\text { - Move gers and } \\
\text { livestock more } \\
\text { - Plant fodder } \\
\text { - Reserve and } \\
\text { rotate pastures } \\
\text { - Give perennial } \\
\text { plants } \\
\text { - Provide fencing } \\
\text { studies } \\
\text { - Build bird } \\
\text { perches to } \\
\text { reduce rodents }\end{array}$ \\
\hline Declining Water Levels & $\begin{array}{l}\text { - Build wells } \\
\text { - Shoot clouds } \\
\text { - Ovoo worship } \\
\text { - Plant trees }\end{array}$ & $\begin{array}{l}\text { - Dig wells } \\
\text { - Shoot clouds } \\
\text { - Stop cutting trees }\end{array}$ & - Build wells \\
\hline Increasing Fire/Disaster & $\begin{array}{l}\text { - Humans should be more } \\
\text { careful } \\
\text { - Move near water }\end{array}$ & - Stop fires & $\begin{array}{l}\text { - Collaborate to } \\
\text { stop fire } \\
\text { - Help each other } \\
\text { when dzud } \\
\text { comes }\end{array}$ \\
\hline Declining Wildlife Presence & - Increase marmot & - Stop hunting & $\begin{array}{l}\text { - Protect animals } \\
\text { from hunting }\end{array}$ \\
\hline Other General Ideas & $\begin{array}{l}\text { - Not helpful } \\
\text { - Do not know } \\
\text { - Stop thieves } \\
\text { - Prepare for winter }\end{array}$ & $\begin{array}{l}\text { - Not helpful } \\
\text { - Do not know } \\
\text { - Support herder income } \\
\text { - Listen to herders } \\
\text { - Provide less welfare } \\
\text { - Incentivize young herders }\end{array}$ & $\begin{array}{l}\text { - Not helpful } \\
\text { - Do not know } \\
\text { - Support herders } \\
\text { - Pay for herder } \\
\text { projects } \\
\text { - Collaborate/ } \\
\text { communicate } \\
\text { - Host meetings/ } \\
\text { trainings } \\
\text { - Gather fallen } \\
\text { trees } \\
\text { - Protect land area }\end{array}$ \\
\hline
\end{tabular}

We propose two explanations for the contradictions between soum-scale meteorological data and herder observations. First, overall, the resolution in the meteorological dataset for these soums may be too coarse to detect herder observations of finer scale variability, as suggested by Klein et al. (2014) for similar mismatches in Tibet. In our study, there were 0-1 stations sampled, on average, in each of our soums, resulting in sparse coverage of fine-scale meteorological differences within each. Herder observations likely include fine-scale observations of multiple indicators of change across habitats in pastures near their homesteads over time (Gantuya et al. 2021). This means the comparison between meteorological data and herder observations may not cover the same geographic area and definitely not the same diversity of habitats, and thus could be prone to mismatch (Marin 2010). In this situation, we would expect matches between these two knowledge sources to occur where there is strong consensus among herders on the 
direction and magnitude of change, which should indicate the change likely applies over wide areas. This may apply to the strong declines in rainfall seen in desert steppe soums (Fernández-Giménez et al. 2015), steppe soums (this study, Fernández-Giménez et al. 2015), and forest steppe soums (this study, Fassnacht et al. 2018).

A second and related explanation for these mismatches may lie with the level of complexity of the information inherent in the two knowledge sources. Like other resourcedependent people, pastoralists integrate several variables and mark extreme events as they relate to periods of normality (Berkes and Berkes 2009). Gantuya et al. (2021) found that Mongolian herders observed long-term directional trends across multiple decades, shorter term (2-10 year) cyclical regeneration of vegetation after disturbance, and shorter term (seasonal or one year) fluctuations caused by weather over 32 indicators in 14 different habitats at these three different time scales. As in our study, herders are integrating all this information into complex causal 'systems models' that they use to adapt to change. We propose that, despite the presence of some bias in herder observations, they provide a sophisticated understanding of change at the soum level while meteorological data and predictions can be scarce and uncertain (Marin 2010).

\section{Herder Observations of the Causes and Consequences of Change}

The systems model summarizes associations and flows of impact between variables and plays a unique, central role in our results. We expand the scope of other Eastern Asia models, organized around similar core elements, by including social-political drivers (Sternberg 2008; Hopping et al. 2016). Future models should disclose whether all causal relationships displayed are derived from pasture users themselves or surmised by researchers. In our model we attempted to directly reflect herder responses, but would have benefitted from more herder participation through mapping workshops (Knapp et al. 2011).

The systems model highlights how herders attributed environmental changes to both proximate and ultimate causes, allowing us to see a more complete picture of their social-ecological system. For instance, according to herders in our study and others, a proximate cause for the decline in pasture quality was increasing livestock numbers (Sternberg 2008; Fernández-Giménez et al. 2015). This incomplete picture, however, does not address the fact that herders ascribe the ultimate cause of increased stocking rates to both external herders from other soums moving into local pastures and the shift towards a new incentive structure through privatization that rewards livestock quantity over quality (Bruegger et al. 2014). "After privatization," an Undurshireet herder explained, "everyone increased their livestock. Where there were green plants is now dust." Degraded pastures, in turn, decrease the quality of livestock products (meat, dairy, wool, etc.) (Fig. 2). Our systems model suggests the need for multi-scalar approaches to improve grassland health (Khishigbayar et al. 2015) that tackle both proximate and ultimate causes of change. Such policies could target livestock density and pasture rotation regimes, but also carbon emissions and the lack of functioning markets for livestock products (Fig. 2).

Herders report complex, systemic change that combines physical (pasture, water, etc.) and social (economic, political, etc.) influences. Our systems model, for example, depicts the coupled drivers of water loss. Herders in Yeroo view mining as exacerbating climate-induced drying by diverting publicly available water sources, as occurred in Lake Ulaan in the Gobi (Fig. 2; Jackson 2018). Adequate water management might include stronger enforcement of mining standards as well as more global climate change mitigation efforts.

\section{Adaptation and Policy Implications}

Effective adaptation at the appropriate scale is exceedingly important due to increased social and ecological unpredictability in rangelands worldwide, including the Mongolian steppe (Middleton 2018; Mijiddorj et al. 2019). Furthermore, adaptation strategies must be specific to place and match the heterogeneity of change we have documented across ecological zones (Tables 2-3; Khishigbayar et al. 2015). Our data show that Mongolian herders are already adapting their management practices to the changes they reported according to their location.

Perceptions of ecosystem dynamics play a strong role in resource management (Fernández-Giménez 1993). We prioritize livestock herder adaptation recommendations because local perceptions may differ from regional or national strategies (Wu et al. 2015). Furthermore, many existing researcher and NGO preparedness proposals lack transparency as to which herders, if any, were consulted in creating recommendations (Wu et al. 2015; Hahn 2018). One report acknowledged the need for more herder inclusion, but then did not include herders in the decision-making process due to transportation barriers (FAO 2014). In other cases in Mongolia, programs implemented or modified policies contrary to the herder perspectives they elicited (Hahn 2018).

Several rangeland studies have documented adaptation strategies employed by resource users, yet fewer seek their perceptions about the governance roles of other actors in the pastoral system (Liu and Wang 2012; Nzeadibe et al. 2012; Karimi et al. 2018). Other Mongolian studies have addressed who should possess or own pastures and who should make decisions around stocking rates and movements (Fernández- 
Giménez and Batbuyan 2004; Kamimura 2013). Our study complements these findings by asking herders about the role of government and CBRMs in relation to specific environmental concerns. In our study and in China's Qinghai Tibetan Plateau, herders view it as the government's role to help support their livelihoods by providing needed technical and social services (Wu et al. 2015). Chinese herders, however, adopted adaptation strategies, like fencing and reseeding pastures, that herders in our study saw as the exclusive purview of government and CBRM actors (Wu et al. 2015). Western Mongolia herders (Altmann et al. 2018), as in our study, suggested that herders move campsites more often, decrease livestock numbers, water pastures, and reduce insects. Some in each study took a more spiritual approach, suggesting more religious ceremonies, often called $O$ voo worships, to increase water levels. Other herders in both studies reported that they did not know how to adapt to the changes experienced in their pasturelands (Altmann et al. 2018).

Our adaptation table (Table 5) intersects with our systems model framework (Fig. 2) by providing insight into which actors may best address different levels of socialenvironmental change. For instance, it may be more effective for the national government to respond to broad-scale, primary drivers of change in the outer ring of the systems model, as seen through recommendations for restrictions to land use or pastoral practices, such as hunted species protections. CBRM organizations might mitigate more intermediary drivers of change, such as through recommendations for dzud response collaboration. Lastly, local herders may initiate adaptations more appropriate for an inner ring phenomenon in the systems model, such as recommendations we heard for pasture rotation and rodent control (Fig. 2; Table 5). While Mongolia's emergency preparedness efforts do detail a division of roles, national and foreign-aid reports tend to discount the level of localized control (Hahn 2018).

Sternberg (2008) hypothesized that herders in westcentral Mongolia still viewed building wells as the government's responsibility because this was the structure during Soviet times. Herders in our study, however, considered this responsibility overlapping between all three of the actors we discussed, signifying a potential shift in their perceived responsibility as more time has passed since the fall of communism. Recent literature depicts herder agency, not only in bearing some responsibility for current conditions, but also in challenging the government and corporations to better address their environmental and livelihood concerns. When herders suggest that they themselves can stop mining from occurring, they may be harkening to past successes of grassroots herder organizations (Table 5). Notably, the "River Movements" garnered broad appeal to leverage the Mongolian government to prohibit mining at river headwaters in 2009 (Campbell and Hatcher 2019). Due to rising economic disparities, herders have asserted their adaptive capacity in other ways by seeking alternative incomes, like staking their own claim to small-scale, artisanal mining (Lahiri-Dutt and Dondov 2017; Mijiddorj et al. 2019).

Internationally financed large-scale mining operations have formed their own ties with the national government since the 1990s mineral resource boom, and thus been able to weaken policies and counteract civil society reform (Byambajav 2015; Jackson 2018). Herders can better account for government and non-government structures and their interactions to effectively pressure change (Fernández-Giménez and Batbuyan 2004; Fernández-Giménez et al. 2008). It appears mutually beneficial for government and international development organizations that support CBRMs to better document pastoral system interactions to tailor their support (Hahn 2018).

Policy recommendations must account for the diffuse governance landscape of post-Soviet Mongolia and competing public and private interests. Rangeland studies and reports can better differentiate the scale of their recommendations. Local knowledge is helpful in this determination but is too often used only to identify herder adaptation instead of also their input for other stakeholders. Our interview questions helped identify herders' perceptions of how adaptation policy is structured in Mongolia. Polycentric governance systems, with nodes of decision making and communication between different institutional levels, can bolster resilient resource governance in social-ecological systems (Andersson and Ostrom 2008; Ostrom 2010).

\section{Conclusions}

To our knowledge, this is one of the first studies to fully link drivers of change, change trends, impacts of change and local adaptations to change, based on local knowledge. A more complete picture of the whole system builds resilience and leaves fewer surprises. We found that combining Mongolian herder TEK with physical science monitoring enhanced our findings of the causes and effects of environmental trends across ecological zones. Additionally, TEK offered key insights into corresponding and appropriate adaptation strategies (Berkes 2008; Hopping et al. 2016). Our Mongolia study findings fit within and contribute to broader conversations around the sustainability of temperate grasslands, considered some of the most imperiled ecosystems globally (Fernández-Giménez et al. 2018). Localized understandings of change can enhance resilience in pastoral communities facing interacting climate, land use, and governance shifts. Future studies should facilitate more active learning in partnership with local resource users and consider who within herding groups is most vulnerable to the drivers of change documented (Smith 1999; Yeh 2016; Hruska et al. 2017). Collaborative, co-produced science can counter unpredictability and support local resource management in the face of complex social-ecological change. 
Acknowledgements We would foremost like to thank the 60 herders we interviewed, and their families, who invited us into their homes, sharing their time and insight. In addition, the soum government leaders who advised us on best practices for each location. They were, respectively: Oyun, Boloroo, and Selenge. Cross-national collaborators from the Mongolian Rangelands and Resilience project, or MOR2, based at the Warner College of Natural Resources at Colorado State University, and from Nutag Partners, based in Ulaanbaatar, Mongolia, helped guide our field research. They include, but are not limited to: Dr. Batkhishig Baival, Dr. Tungalag Ulambayar, Altanzul Tsevlee, and Nomin-Erdene Sukhbold. During the analysis we benefited from the insight and experience of Dr. Niah Venable, Dr. Jay Angerer, Michael Heiner, Dr. Christine Schuetze, and the UCSC Environmental Studies Department.

Author Contribution All authors contributed to the study conception and design. Indiana Reid-Shaw and Azjargal Jargalsaihan collected the data. The first draft of the manuscript was written by Indiana ReidShaw and all authors commented on previous versions of the manuscript. Robin S. Reid and María E. Fernández-Giménez contributed the most to revisions.

Funding We thank the Swarthmore College Social Sciences Division, the Center for Collaborative Conservation at Colorado State University, and the NSF Dynamics of Coupled Natural and Human Systems $(\mathrm{CNH})$ Program award BCS-1011801 for funding this study.

Data Availability The datasets generated during and/or analyzed during the current study are available from the corresponding author on reasonable request.

\section{Declarations}

Informed Consent Informed consent was obtained for all respondents and research was conducted in line with our approved IRB protocol (Colorado State University IRB protocol 11-2514H).

Conflict of Interest The authors declare that they have no conflict of interest.

Open Access This article is licensed under a Creative Commons Attribution 4.0 International License, which permits use, sharing, adaptation, distribution and reproduction in any medium or format, as long as you give appropriate credit to the original author(s) and the source, provide a link to the Creative Commons licence, and indicate if changes were made. The images or other third party material in this article are included in the article's Creative Commons licence, unless indicated otherwise in a credit line to the material. If material is not included in the article's Creative Commons licence and your intended use is not permitted by statutory regulation or exceeds the permitted use, you will need to obtain permission directly from the copyright holder. To view a copy of this licence, visit http://creativecommons.org/licenses/by/4.0/.

\section{References}

Agrawal, A. (1995). Dismantling the divide between indigenous and scientific knowledge. Development and Change 26:413-439.

Agrawal, A. and C. Gibson. (2001). Communities and the environment: ethnicity, gender, and the state in community-based conservation. Rutgers University Press, New Brunswick, N.J.
Alexander, C., Bynum, N., Johnson, E., King, U., Mustonen, T.,Neofotis, P., Oettlé, N., Rosenzweig, C., Sakakibara, C., Shadrin, V., Vicarelli, M., Waterhouse, J., and Weeks, B. et al. (2011). Linking indigenous and scientific knowledge of climate change. BioScience 61:477-484.

Altmann, B.A., Jordan, G. and Schlecht, E. (2018). Participatory mapping as an approach to identifygrazing pressure in the Altay Mountains, Mongolia. Sustainability (10)6:1960.

Andersson, K.P. and Ostrom, E. (2008). Analyzing decentralized resource regimes from a polycentric perspective. Policy Sciences 41(1):71-93.

Angerer, J., Han, G., Fujisaki, I. and Havstad, K. (2008). Climate change and ecosystems of Asiawith emphasis on Inner Mongolia and Mongolia. Rangelands Archives 30:46-51.

Auerbach, C.F. and Silverstein, L.B. (2003). Qualitative data: An introduction to coding and analysis. New York University Press.

Batjargal, Z. (1997). Desertification in Mongolia; in RALA Report No 200 (ed.) Agricultural Research Institute of Iceland (Iceland: Keldnaholt) pp 1-149.

Berkes, F. (2008) Sacred Ecology 2 Routledge Taylor and Francis, New York, NY.

Berkes, F. and Berkes, M.K. (2009). Ecological complexity, fuzzy logic, and holism in indigenous knowledge. Futures 41 (1), 6-12.

Bruegger, R.A., Jigjsuren, O. and Fernández-Giménez, M.E. (2014). Herder observations of rangeland change in Mongolia: Indicators, causes, and application to community-based management. Rangeland Ecology \& Management 67:119-131.

Bruun, O. and Odgaard, O. (1996). Mongolia in Transition. Psychology Press.

Bryman, A. (2012). Social Research Methods. 4th edition. New York: Oxford University Press.

Byambajav, D. (2015). The river movements struggle in Mongolia. Social Movement Studies 14: (1) 92-97.

Campbell, B., and Hatcher, P.. (2019). Neoliberal reform, contestation and relations of power in mining: Observations from Guinea and Mongolia. Extractive Industries and Society-an International Journal 6(3):642-653.

Carbutt, C., Henwood, W.D. and Gilfedder, L.A. (2017). Global plight of native temperate grasslands: going, going, gone? Biodiversity Conservation 26:2911-2932.

Charmaz, K. (2006). Constructing Grounded Theory. London: Sage Publications.

Chen, J., Del Genio, A.D., Carlson, B.E., Bosilovich, M.G. (2008). The spatiotemporal structure of twentieth century climate variations in observations and reanalyses. part I: long-term trend. J. Climate 21, 2611-2633.

Corbin, J.M. and Strauss, A. (1990). Grounded theory research: procedures, canons, and evaluative criteria. Qualitative Sociology 13:3-21.

CPC Global Daily Temperature. (2017). NOAA Earth System Research Laboratory, https://www.esrl.noaa.gov/psd/data/gridded/data.cpc. globaltemp.html.

Dagvadorj, D., Natsagdorj, L., Dorjpurev, I. and, Namkhainyam, B. (2009). Mongolia: assessment report on climate change. Ulaanbaatar: Ministry of Environment, Nature and Tourism pp. 228.

Danielson, S., Webler, T. and Tuler, S.P. (2010). Using Q method for the formative evaluation of public participation processes. Society and Natural Resources (23)1:92-96.

Davis, A. and Wagner, J. (2003). Who knows? On the importance of identifying "experts" when researching local ecological knowledge. Human Ecology 31:463-489.

Dumbe, Y., Zakaria, S.M.and Eshun, G. (2018). The nexus of traditional ecological knowledge and ecotourism development: a case of bobiri forest and butterfly sanctuary, Ghana. Tourism and Leisure 7(2). 
Fan, Y. and Van den Dool, H.A. (2008). Global monthly land surface air temperature analysis for 1948-present. Journal of Geophysical Research: Atmospheres 113, D01103.

Fassnacht, S.R., Allegretti, A.M., Venable, N.B.H., Fernández-Giménez, M.E., Tumenjargal, M.E., Kappas, M., Laituri, M., Batbuyan, B. and Pfohl, A.K.D. (2018). Merging indigenous knowledge systems and station observations to estimate the uncertainty of precipitation change in Central Mongolia. Hydrology 5:46.

Fernández-Giménez, M.E. (1993). The role of ecological perception in indigenous resource management: a case study from the Mongolian forest-steppe. Nomadic Peoples 33:31-46.

Fernández-Giménez, M.E. (2000). The role of Mongolian nomadic pastoralists' ecological knowledge in rangeland management. Ecological Applications 10:1318-1326.

Fernández-Giménez, M.E. and Batbuyan, B. (2004). Law and disorder: local implementation of Mongolia's land law. Dev. Change 35 141-65.

Fernández-Giménez, M.E., Kamimura, A., and Batbuyan, B. (2008). Implementing Mongolia's Land Law: Progress and Issues. Japan: The Central for Asian Legal Exchange (CALE), Nagoya University.

Fernández-Giménez, M. E., B. Batkhishig, B. Batbuyan, and T. Ulambayar. (2014). Lessons from the dzud: Community-based rangeland management increases adaptive capacity of Mongolian herders to winter disasters. World Development 68:48-65.

Fernández-Giménez, M. E., Angerer, J.P., Allegretti, A.M., Fassnacht, S.R., Byamba, A., Chantsallkham, J., Reid, R.S., Venable, N.B.H. (2015). Integrating herder observations, meteorological data, and remote sensing to understand climate change patterns and impacts across an eco-climatic gradient in Mongolia. Proceedings of Building Resilience of Mongolian Rangelands: A Transdisciplinary Research Conference, Ulaanbaatar Mongolia, June 9-10, 2015.

Fernández-Giménez, M.E., Allington, G.R.H., Angerer, J., Reid, R.S., Jamranjav, C., Ulambayar, T., Hondula, K., Baival, B., Bajjav, B., Altanzul, T., and Baasandorj, Y. (2018). Using an integrated social-ecological analysis to detect effects of household herding practices on indicators of rangelands resiliences in Mongolia. Environmental Research Letters 13075010.

Food and Agriculture Organization of the United Nations (FAO) (2014). Report on Ruminant Supply Chains in Mongolia: A Preliminary Assessment of Strategies for Improving Returns, Risk Management, and Productivity. FAO Regional Office for Asia and the Pacific. Bangkok, Thailand.

Galvin, K.A., Reid, R.S., Behnke, R.H. and Hobbs, N.T. (2008). Fragmentation in semi-arid and arid landscapes: Consequences for human and natural systems. Springer, Dordrecht.

Galvin, K.A. (2009). Transitions: pastoralists living with change. Annual Review of Anthropology 38:185-198.

Gantuya, B., Biró, M., Molnár, Á., Agar, Á., Sharifian Bahraman, A., Babai, D., Molnár. Z. (2021). How Mongolian herders perceive ecological change in a "stable" landscape. Ecology and Society 26(2):21.

Gao, W., Angerer, J.P., Fernández-Giménez, M.E. and Reid, R.S. (2015). Is overgrazing a pervasive problem across Mongolia? An examination of livestock forage demand and forage availability from 2000 to 2014. Building Resilience of Mongolian Rangelands: A Transdisciplinary Research Conference, Ulaanbaatar, Mongolia.

Gómez-Baggethun, E., Corbera, E. and Reyes-García, V. (2013). Traditional ecological knowledge and global environmental change: research findings and policy implications. Ecology and Society (18) 4 .

Goulden, C.E., Mead, J., Horwitz, R., Goulden, M., Nandintsetseg, B., McCormick, S., Boldgiv, B. and Petraitis, P.S. (2016). Interviews of Mongolian herders and high resolution precipitation data reveal an increase in short heavy rains and thunderstorm activity in semiarid Mongolia. Climatic Change 136:281-295.

Hahn, A. (2018). Complexity of Mongolian stakeholders' dzud preparation and response. Natural Hazards 92:127-143.

Harris, I., Jones, P.D., Osborn, T.J. and Lister, D.H. (2014). Updated high-resolution grids of monthly climatic observations - the CRU TS3.10 Dataset. International Journal of Climatology 34:623-642.

Herrick, J.E., Brown, J.R., Bestelmeyer, B. and Andrews, S.S. (2012). Revolutionary land use change in the 21st century: Is (rangeland) science relevant? Rangeland Ecology \& Management 65:590-598.

Hopping, K.A., Yangzong, C. and Klein, J.A. (2016). Local knowledge production, transmission, and the importance of village leaders in a network of Tibetan pastoralists coping with environmental change. Ecology And Society 21:21.

Hruska, T., Huntsinger, L., Brunson, M., Li, W., Marshall, N., Oviedo, J. L., Whitcomb, H. (2017). Rangelands as Social-Ecological Systems. In: Rangeland Systems: Processes, Management, and Challenges. (ed Briske, David D.) Springer International Publishing.

Huntington, H.P. (1998). Observations on the utility of the semi-directive interview for documenting traditional ecological knowledge. Arctic 51(3):237-242.

Jackson, S.L. (2015). Dusty roads and disconnections: Perceptions of dust from unpaved mining roads in Mongolia's South Gobi province. Geoforum 66:94-105.

Jackson, S.L. (2018). Abstracting water to extract minerals in Mongolia's South Gobi Province. Water Alternatives - An Interdisciplinary Journal on Water Politics and Development 11 (2):336-356.

Jamsranjav, C., Reid, R.S., Fernández-Giménez, M.E., Tsevlee, A., Yadamsuren, B. and Heiner, M. (2018). Applying a dryland degradation framework for rangelands: The case of Mongolia. Ecological Applications 28:622-642.

Jamsranjav, C., Fernández-Giménez, M.E, Reid, R.S. and Adya, B. (2019). Opportunities to integrate herders' indicators into formal rangeland monitoring: An example from Mongolia. Ecological Applications 29(5):e01899.

Joyce, L.A., Briske, D.D., Morgan, J.A., Brown, J.R., Polley, H.W., McCarl, B.A., and Bailey, D.W. (2013). Climate change and North American rangelands: Trends, projections, and implications. Rangeland Ecology \& Management 66:493-511.

Kakinuma, K. and Takatsuki, S. (2012). Applying local knowledge to rangeland management in northern Mongolia: do 'narrow plants' reflect the carrying capacity of the land? Pastoralism: Research, Policy and Practice 2, 23.

Kamimura, A. 2013. Pastoral Mobility and Pastureland Possession in Mongolia. In: Yamamura et al. (eds). The Mongolian Ecosystem Network: Environmental Issues Under Climate and Social Changes. Utrecht: Springer. pp.187-203.

Karimi, V., Karami, E. and Keshavarz, M. (2018). Vulnerability and Adaptation of Livestock Producers to Climate Variability and Change. Rangeland Ecology and Management 71(2):175-184.

Kassam, K.A. (2009). Viewing change through the prism of indigenous human ecology: Findings from the Afghan and Tajik Pamirs. Human Ecology 37:677-690.

Khishigbayar, J., Fernández-Giménez, M.E., Angerer, J.P., Reid, R.S., Chantsallkham, J., Baasandorj, Y. and Zumberelmaa, D. (2015). Mongolian rangelands at a tipping point? Biomass and cover are stable but composition shifts and richness declines after 20 years of grazing and increasing temperatures. Journal of Arid Environments. 115.100-112.

Klein, J.A., Hopping, K.A., Yeh, E.T., Nyima,Y., Boone, R.B. and Galvin, K.A. (2014). Unexpected climate impacts on the Tibetan Plateau: Local and scientific knowledge in findings of delayed summer. Global Environmental Change-Human and Policy Dimensions 28:141-152. 
Knapp, C.N., and Fernández-Giménez, M.E. (2009). Understanding change: integrating rancher knowledge into state-and-transition models. Rangeland Ecology and Management 62:510-52.

Knapp, C.N., Fernández-Giménez, M.E., Kachergis, E. and Rudeen, A. (2011). Using Participatory Workshops to Integrate Stateand-Transition Models Created With Local Knowledge and Ecological Data. Rangeland Ecology and Management 64:158-170.

La Frenierre, J. and Mark, B.G. (2017). Detecting patterns of climate change at Volcán Chimborazo, Ecuador, by integrating instrumental data, public observations, and glacier change analysis. Annals of the American Association of Geographers 107:979-997.

Lahiri-Dutt, K. and Dondov, H. (2017). Informal mining in Mongolia: livelihood change and continuity in the rangelands. Local Environment 22(1):126-139.

Lewison, R.L., Rudd, M.A., Al-Hayek, W., Baldwin, C., Beger, M., Lieske, S.N., Jones, C., Satumanatpan, S., Junchompoo, and Hines, E. (2016). How the DPSIR framework can be used for structuring problems and facilitating empirical research in coastal systems. Environmental Science and Policy $56: 110-119$.

Liu, S. and Wang, T. (2012). Climate change and local adaptation strategies in the middle Inner Mongolia, northern China. Environmental Earth Sciences 66:1449-1458.

Lkhasuren, O. (2012). Occupational safety and the health of miners as challenge to policy-making in Mongolia? In: Change in Democratic Mongolia (ed Dierkes, J.).. Brill, Boston, MA:135-147.

Mann, H.B. Nonparametric tests against trend. Econometrica 1945, $13,245-259$.

Marin, A. (2010). Riders under storms: Contributions of nomadic herders' observations to analysing climate change in Mongolia. Global Environmental Change-Human and Policy Dimensions 20:162-176.

Meadows, D.H. and Wright, D. (2008). Thinking in Systems: A primer. White River Junction, VT: Chelsea Green Publishing.

Middleton, N. (2018). Rangeland management and climate hazards in drylands: dust storms, desertification and the overgrazing debate. Natural Hazards 92:57-70.

Mijiddorj, T.N., Ahearn, A., Mishra, C. and Boldgiv, B. (2019). Gobi herders' decision-making and risk management under changing climate." Human Ecology 47 (5):785-794.

Mongolia General Statistical Database (2021) National Statistical Committee. Ulaanbaatar, Mongolia. https://www.1212.mn.

Nightingale, A. (2016). Adaptive scholarship and situated knowledges? Hybrid methodologies and plural epistemologies in climate change adaptation research. Area 48.1, 41-47

Nzeadibe, T.C., Egbule, C.L., Chukwuone, N.A., Agwu, A.E. and Agu, V.C. (2012). Indigenous innovations for climate change adaptation in the Niger Delta region of Nigeria. Environment, Development and Sustainability 14:901-914.

National Statistical Office of Mongolia. Monthly Bulletin of Statistics. (2019). Mongolia Livestock Statistical Data. Socio-Economic Situation of Mongolia. National Statistical Office of Mongolia, Ulaanbaatar, Mongolia. www.nso.mn.

Ojima, D. and Chuluun, T. (2008). Policy Changes in Mongolia: Implications for Land Use and Landscapes. In: Fragmentation in SemiArid and Arid Landscapes: Consequences for Human and Natural Systems (eds. Galvin, K.A., Reid, R.S., Behnke, Jr., R.H.. and Hobbs, N.T.) (Springer Netherlands,). 179-193.

Orgil, D., Tserenchimed, C., Tserenjav, J., Shinetsetseg, D., MunkhErdene, O., Munkhdchuluun, G., Bayaraa, J., Odbayar, P. and Erdenebold, B. (2011). Environmental Review of Umnugobi Province and Negative Influence of Mining Industry to Livestock Health. National Veterinarian Hygiene Laboratory Center, Ulaanbaatar, pp. 90-93.

Ostrom, E.A. (2010). Beyond markets and states: polycentric governance of complex economic systems. American Economic Review 100:641-672.

Pohlert, T. (2016). The Pairwise Multiple Comparison of Mean Ranks Package (PMCMR). 27.
Ramirez, E. (2014). U.S. Releases Enhanced Shuttle Land Elevation Data. Available at: http://www2.jpl.nasa.gov/srtm/ .

Reid, R.S., Fernández-Giménez, M.E., and Galvin, K.A.. (2014). Dynamics and resilience of rangelands and pastoral peoples around the globe. Annual Review of Environment and Resources 39:217-242.

Roba, H.G. and Oba, G. (2008). Integration of herder knowledge and ecological methods for land degradation assessment around sedentary settlements in a sub-humid zone in northern Kenya. International Journal of Sustainable Development \& World Ecology 15:251-264.

Sankey T.T., Sankey, J.B., Weber, K.T. and Montagne, C. (2009). Geospatial assessment of grazing regime shifts and sociopolitical changes in a Mongolian rangeland. Rangeland Ecology and Management 62:522-530.

Shiklomanov, A.I., Lammers, R.B. and Vorosmarty, C.J. (2002). Widespread decline in hydrological monitoring threatens panArctic research. Eos, Transactions American Geophysical Union (83)2:13-17.

Smith, L. T. (1999). Decolonizing methodologies: research and indigenous peoples. Dunedin, NZ: University of Otago Press.

Somerville, M., Davies, B., Power, K., Gannon, S. and de Carteret, P. (2011). Introduction. In: Place pedagogy change. (eds Somerville, M., Davies, B., Power, K., Gannon, S. and de Carteret, P. Rotterdam: Sense Publishers, 1-12.

Sternberg, T. (2008). Environmental challenges in Mongolia's dryland pastoral landscape. Journal of Arid Environments 72:1294-1304.

Sternberg, T. and Edwards, M. (2017). Desert dust and health: a central Asian review and steppe case study. International Journal of Environmental Research and Public Health 14(11).

Strauss S. and Orlove B. eds (2003). Weather, Climate, Culture Berg, Oxford

Ulambayar, T., Fernández-Giménez, M.E., Batkhishig, B., and Batjav, B. (2017). Social outcomes of community-based rangeland management in mongolian steppe ecosystems. Conservation Letters 10, 317-327.

Ulziikhutag, N. (1989). Characteristics of flora of Mongolia. In: Synopsis of Mongolian flora, (ed Sanchir, C.) State Publishing, Ulaanbaatar, Mongolia. pp.107-148.

Upton, C. (2008). Social capital, collective action and group formation: developmental trajectories in post-socialist Mongolia. Human Ecology $36: 175-188$.

Venable, N.B.H., Fassnacht, S.R., Adyabadam, G., Tumenjargal, S., Fernández-Giménez, M.E., and Batbuyan, B. (2012). Does the length of station record influence the warming trend that is perceived by Mongolian herders near the Khangai Mountains? Pirineos 167:69-86.

Venable, N.B.H., Fassnacht, S.R., Hendricks, A.D. (2015). Spatial changes in climate across Mongolia. Proceedings of Building Resilience of Mongolian Rangelands: A Trans-disciplinary Research Conference (eds Fernández-Giménez, M.E., Batkhishig B, Fassnacht SR, Wilson D.), Ulaanbaatar Mongolia, June 9-10, 2015.

Venable, N.B.H. (2016). May 16. Personal Communication.

Wickham, H. (2016). ggplot2: Elegant Graphics for Data Analysis. Springer-Verlag New York.

Wu, X., Zhang, X., Dong, S., Cai, H., Zhao, T., Yang, W., Jiang, R., Shi, Y. and Shao, J. (2015). Local perceptions of rangeland degradation and climate change in the pastoral society of QinghaiTibetan Plateau. The Rangeland Journal 37:11.

Yeh, E.T. (2016). How can experience of local residents be "knowledge"?' challenges in interdisciplinary climate change research. Area 48.1,2-6.

Yehl, A. (2009). Comprehensive yet "passionate"- discovering qualitative methods: field research, interviews, and analysis. In: The Qualitative Report (eds. Warren, C.A.B. and Tracy, X.K.) 14(4):280-283.

Publisher's Note Springer Nature remains neutral with regard to jurisdictional claims in published maps and institutional affiliations. 